\title{
Social Work in Movement: Marketisation, Differentiation and Managerial Performativity in Sweden and England
}

\author{
John Chandler ${ }^{1}$, Linda Bell ${ }^{2, *}$, Elisabeth Berg ${ }^{3}$, Jim Barry $^{1,3}$ \\ ${ }^{1}$ UEL Royal Docks Business School, University of East London, Docklands Campus, UK \\ ${ }^{2}$ Department of Mental Health, Social Work \& Integrative Medicine, School of Health \& Education, Middlesex University, UK \\ ${ }^{3}$ Human Work Sciences, Department of Business Administration, Technology and Social Sciences, \\ Luleå University of Technology, Sweden \\ *Corresponding Author: L.Bell@mdx.ac.uk
}

\begin{abstract}
This article considers the changing nature of social work in England and Sweden in the context of neoliberal reforms, and the consequences of the ongoing shifts to marketisation and differentiation, managerialism and performativity. Drawing on secondary sources and some interview data from English and Swedish social workers, the article argues that social workers in England and Sweden face similar shifts as marketisation, differentiation, managerialism and its related performativity reshape the occupation, all related to the influence of the macro-context of neoliberalism. 'Evidence based practice' has become elevated as an important approach in line with increasing managerialism and performativity, affecting micro processes of everyday working life. Differences between the two countries lie largely in the timing of reforms and how social workers respond to them in organised ways - through mobilisation within the profession in England and through trades unions and local authorities in Sweden. The changes create uncertainty for social workers; while they are not merely passive victims of change they face difficult conditions in which to forge alternative models of professional practice. Contrary to what might have been expected, given the different social, political and historical legacies in Sweden and England of social democracy and liberalism respectively, comparing the social work occupation in these two countries finds many more similarities than differences in how marketisation, differentiation, managerialism and performativity impact on the occupation.
\end{abstract}

Keywords Social Work, Sweden, England, Marketisation, Performativity, Managerialism, Identities

\section{Introduction}

At different times and in different ways both Sweden and
England became increasingly subject to markets, along with the associated competition and risks, as well as a concern for individualization and the accountabilities of self-responsibilization which accompanied the regimes that followed. Drawing on nineteenth century political liberalism, the pursuit of wealth through self-interest and the inequality that would follow were held up as a public good that could be enjoyed by all as it trickled down to those at the lowest levels of society. Yet the differing social, political and historical legacies of the two countries led to a variation in the in the timing, extent and rigour of these developments; there was greater embeddedness of social democratic norms in Swedish civil society and the enhanced ability of public sector unions there to resist fundamental reform, leading Harvey (2005) to characterize the result as 'circumscribed' neo-liberalism. In both countries the forward march of neo-liberalism was not just the result of periods of Liberal or Conservative party rule. If the Thatcher governments in England in the 1980s were enthusiastic early adopters of neo-liberalism, it also permeated the Labour Party in England under Tony Blair's 'third way'. In Sweden there was an increase in the private sector labour market to provide welfare services, a development that could change social policy (Olofsson 2009).

This is the context in which contemporary social workers found themselves at the end of the 20th century and the early years of the 21 st and it is this period we wish to concentrate on here. As a result of the neo-liberal trends discernible in both countries social work has, since the later decades of the twentieth century, faced what might be described as two interconnected trends: those of marketization and differentiation on the one hand and managerialization and performativity on the other. In many respects these are interlocking and mutually supportive but there are also tensions between them that can lead to increasing uncertainty. A third important issue is the implementation of evidence based practice in both countries which indicates a managerial drive for increased performance in economy, efficiency and 
effectiveness (Harlow et al 2013).

The development of evidence based practice within social work can be seen as an integral part of the development of a managerialized social work practice that - however questioned - helps to create a value base for contemporary social work, both national and international (Nygren, Blom and Moren 2006). Evidence based practice is associated in medicine with what in Sweden are called effect studies, normally comprising randomized control studies of the correlation between certain inputs and results, mainly quantitative in design and based on the epistemology of the natural sciences (Oscarsson, 2009). Even where evidence based practice is founded on a broader range of evidence, based on qualitative studies, it still could be seen as drawing legitimacy from its claim to scientific status. Drawing on the work of Lyotard, Dent and Whitehead (2002 pp. 7-8) argue that the elevation of scientific forms of knowledge over narrative forms provides a discourse of truth about the way things work in society and thereby legitimation for managerial over professional varieties of understanding and knowing, thereby neutralizing or foreclosing political debate. They use Lyotard's concept of performativity to describe the resulting practices. But such performativity is criticised because it alters the relation between users and social workers, with the latter driven to use simple, prescribed methods that are sometimes not updated; whilst at the same time research indicates that social workers are in need of social methods to avoid the vicissitudes of temporary trends and ideologies (Bergmark and Lundström, 2006).

In discussing social work in the two countries Esping Anderson's concept of welfare regimes might be seen as a convenient starting point for our paper, as the UK is considered a liberal variety, and Sweden the social democratic regime (1990; see also Dent 2003: 9-11). However, we have chosen to focus specifically on social work as but one aspect of welfare, following Kasza, who contends that:

“... few national welfare systems are likely to exhibit the internal consistency necessary to validate the regime concept, and ... policy-specific comparisons may be a more promising avenue for comparative research..."

(Kasza, 2002 p. 271)

In light of this, it is considered fruitful to undertake a two-country comparison. Comparing and contrasting social work in two countries might reveal some interesting differences and challenge some taken for granted assumptions about social work in both places. To the extent that we find similar patterns emerging, however, it could point to more general trends and forces at work that might attest to the power of transnational processes. In particular the significance in both countries of trends towards greater marketization and managerialism are highlighted, and how these are connected with neoliberal tendencies is considered.

In the following sections we flesh out and examine marketization and differentiation on the one hand and managerialisation and performativity on the other, continuing with a discussion about the profession of social work in the context of managerial changes and evidence based practice. This latter discussion involves consideration, as indicated above, of some empirical data to illustrate the operationalization of managerial practices and mindsets from the private sector into the public realm at the meso level, since it is this that acts as the glue of wider political and economic forces, dubbed collectively neo-liberalism which operates at the macro level to embed processes of performativity through evidence based practice.

\section{Methods}

We draw on secondary sources, also using some of our own recent qualitative, empirical research in both England and Sweden for illustrative purposes. The English study has involved, to date, 8 semi-structured interviews with professionals who have moved into higher education (identified as 'academic practitioners'), including social work academics who had previously been managers. ${ }^{1}$ In Sweden, semi-structured interviews were conducted with social work managers who dealt with individuals and families. The interviews were focusing on in what way they understood and applied evidence based practice in their daily work. The interviews were conducted with 7 managers in three local authorities. We draw on material from some of these social worker interviews later in the paper as indicative in order to focus on our broader aim which is to consider the implications of the relatively recent growth of evidence based practice in social work in the two countries in question.

These illustrative interviews provide insight into the micro processes of everyday working practices; they suggest that whilst social workers are concerned about developing a body of knowledge in which they can base their practice, they recognize at the same time that this knowledge appears eclectic and is in many ways derivative. A constant challenge for social workers in their everyday working routines thus appears to lie in the construction of knowledge out of practice itself, in order to demonstrate to others that it is 'evidence based'.

\section{Marketisation and Differentiation}

Marketization, as a process of introducing a free market economy, and differentiation, indicative of increasingly privatized or otherwise variegated provision, are present in both countries as the State becomes increasingly dependent on the private or voluntary sector to provide 'public' services. Growing affluence and gaps in public provision have also led to a growth in the number of individuals who turn to the

\footnotetext{
${ }^{1}$ Ethics approval for this study was granted by Middlesex University Health Studies Ethics Committee.
} 
private or third sector for the satisfaction of social needs such as care for older people, or help with mental health problems or drug dependency.

In both countries legislative change has opened up opportunities for local authorities to subcontract services to private entrepreneurs and third sector organizations (for Sweden see Holmberg and Henning, 2003; for England see Leach et al., 1994 pp. 35-37). These changes have opened up opportunities for professional social workers to start their own private business as care providers or consultants, acting in some cases as the go-between for local authorities and individual users of the services concerned (Löfstrand, 2009). In England the NHS \& Community Care Act of 1990, implemented within social services in 1993 (reluctantly so in some local authorities), introduced a purchaser-provider split that also fragmented services between those for children \& families and those for adults with specific needs.

In both countries these changes were associated with a growing consumerism, as social workers were given responsibility to involve clients/service users in decisions about appropriate interventions and services (Hollander, 2006, see also Hugman, 2005, as well as Clarke and Newman 1997). Needs were increasingly seen in individualistic rather than social terms, something that might be seen as a return to social work's origins with more emphasis on individualism, less on changing the social environment. If there is a difference from 19th century forms of social support for the vulnerable, however, it is that this individualism is more of a consumerist 'possessive' kind, and less moralistic. In both England and Sweden, for example, 'personalized' care and personal budgets have developed in health and social care which are meant to give individual users more say over how their needs are catered for. This can encourage the use of private care in place of direct State service provision. In this, as Clarke puts it:

“...[m]anagerialism ... [has been seen as] ... the dominant organizational strategy (and discourse) to coordinate public services - and ... [performance] ... a particular development within this framework of organizational control"

(Clarke, 2004: 128-129).

The differentiation of social work through its provision in a greater range of organizational settings and roles can also be seen as something of a return to the occupation's origins in a diverse range of organizations in the public, private and voluntary sectors. It does, however, pose great challenges for occupational identity and training. The inherent instability of private providers who are dependent on the vagaries of the market, and of the changing availability and cost of finance, make for uncertainty for those working within or with such organizations; whilst those in the third sector are scarcely labouring under more certainty as income streams are apt to wax and wane and barriers to entry are relatively low bringing the possibility of new competition from other suppliers. Also, while differentiation is closely related to marketisation it can also occur within the public sector.

Thus in England a 'purchaser-provider' split resulted from the Community Care Act (1990) and unified Social Services Departments have now been split up and replaced by arrangements which separate care of adults from that of children and families. While this might simply be seen as a change of boundaries, such reorganization itself can create uncertainties as roles and relationships change and people take time to adjust to new frameworks.

In Sweden, while there is more stability of organizational arrangements within the public sector, there is now increasing use of private and voluntary sector organizations to provide care, as we have seen (Löfstrand 2009). However, there has always been, since social welfare services were established, a clear demarcation of social service units and managers for children's care and for family and individual care (for example, using the model of social pedagogy (Erikkson, 2014), and the care for elderly and people with disability based on education and organization.

Despite these changes, some protection has come from the introduction of legally recognized 'protected status' for the occupational title of 'social worker' in England. This requires social workers to have certain recognized social work qualifications (of degree level) and they must currently maintain their registration status with the Health \& Care Professions Council (HCPC) to be able to practise. Mirroring the earlier multiplicity of social work occupations, this registration applies to job roles which include 'a substantial amount of social work' (according to the previous regulator, the General Social Care Council, 2011) and embraces those with job titles such as 'practice manager', 'senior practitioner', 'team manager' and 'service manager'. However, the UK government subsequently announced that the GSCC itself was to be abolished and its registration functions transferred to the Health and Care Professions Council, which regulates a number of different professions. In Sweden there is no similar protection for the title of social worker, the only exception being for social workers working with children at risk. These social workers must have experience of the kind of enquiry needed to investigate children in need of care and protection. The protection for social work as an occupation has to come from trade unions and from within local and national governments, sometimes of a coalition nature.

Significant, too, in the English context at least, was the final report of the Social Work Taskforce (2009) which suggested a number of changes that appear to bolster a generic 'profession' of social work including further reform of education and training, a supported and assessed first year for newly qualified social workers and the development of a single, nationally recognized, career structure. There is also some recent evidence that social workers in England are attempting to 'reclaim' a profession focused much more clearly on values related to 'social justice' and to relationship-based practice with their clients/ service users. According to Lawler (2000), management itself has a vast 
potential to alter the relationships of power, culture, control and responsibility. He also points out that the result of leadership is uncertain as an influencing factor. Leadership is a human process that is open for both mediation and changes and can to some extent be rebellious.

\section{Managerialisation and Performativity}

Alongside trends to marketization and differentiation, to some extent as a direct result, both countries have seen demands to make social work more efficient and results-oriented. Acting as the organizational glue of neo-liberalism (Clarke, 2004), the new public management (NPM) emerged from the late 1970s onwards (Hood et al., 1999: 89-90) to operationalize its principles across what was becoming a disaggregated and dispersed state (Clarke and Newman, 1997) through policies that elevated varieties of privatization and performativity. Coming to Sweden slightly later than England (the late 1980s in Sweden compared to the early 1980s in England) the introduction of the NPM had a number of consequences. Pollitt and Bouckaert characterize the period since 1980 as witness to:

“... a pandemic of public management reforms, which ... swept across much of the OECD world. The working lives of millions of public officials ... [were] ... substantially altered (and, in some tens of thousands of cases, prematurely terminated)"

(Pollitt and Bouckaert, 2000 p 1)

In practice the NPM drew on managerial techniques and their associated mindsets that had been developed in the private sector. The emphasis was placed on shifting workers' allegiance away from their occupational identifications, to an orientation that favoured the organizations in which they worked, and where they were vulnerable to managerial control. To this end, cadres of managers developed across the public sector who were recruited either from within existing occupational ranks, or from outside (Exworthy and Halford, 1999).

In all this, private sector techniques such as cultural re-engineering to win the hearts and minds of reluctant or recalcitrant workforces thought to be in need of inspirational leadership, and performance management to ensure commitment and track its progress in meeting managerially designed targets or benchmarks, became the order of the day, introduced as the means to control public sector workers. The development of evidence based practice within social work can also be seen as an integral part of this development of a managerialized social work practice.

Here we see the use of metrics, quantitative measures developed to track the performance of public sector employees, including of course social workers, in order to hold them to account in meting specific pre-set targets and performance generally. This reliance on metrics is in line with what Lyotard has called performativity, which seeks to objectify human processes in the name of science as faith in narrative fades (Dent and Whitehead 2002), the former offering a measure of certainty to those managers anxious to justify the pursuit of parsimony in public provision.

\section{Managerialism, Social Work and Evidence-based Practice}

In considering developments in the English case, Carey (2008) focuses on the aftermath of the Griffiths Report and suggests that two outcomes could be seen as particularly problematic. Firstly, that care managers 'the preferred name in the UK for social workers [and others] dealing mainly with adults and older people who require social care support in the community' (op cit: Abstract) no longer spent much time with clients, to focus instead on brokering services. The picture was complicated by the fact that some 'care managers' were employed from professions such as occupational therapy, and that their managers then found they needed further training to acquire 'social work skills' in order to do the job. Secondly, Carey suggests that 'many aspects of care management practice promote forms of inequality, especially amongst already disadvantaged groups' (Carey 2008: 308), making this approach difficult to defend ethically. Similar developments have also been evident in Sweden (author, 2008).

Surrounding this, there has been continuing debate about the uncertain role of theory in relation to social work practice, a debate that is continuing and perhaps becoming more acute with recent emphasis being placed on evidence based practice. In order to explore such issues we now draw on the interviews undertaken with professional social workers in both countries in different projects. As noted earlier, these projects involved firstly a series of qualitative interviews carried out in England at different institutions with social work and health educators who had moved into higher education from practice, including from management positions. Extracts from two of the social worker interviews from this project are included here, to illustrate longstanding issues within social work and social work education concerning how social workers consider theory can be applied to practice, under the developing influence of neo-liberal policies. In northern Sweden, a related project involved interviewing social workers and managers about the relevance of evidence based practice to both managers and front line workers was initiated in 2010 and is ongoing as we write this paper.

We have chosen examples in what follows to illustrate the implications of a shift in social welfare services linked to neo-liberal changes in society where the NPM has been acting as its organizational glue. Possibly most importantly, this shows the uncertainty that professional social workers feel about the changing times in which they are enmeshed.

The following extracts derive from these interviews with two English and two Swedish social workers, with those from England also having been involved in social work education, as illustrative in order to consider some of the 
implications. The first interviewee is very doubtful about the content as well as the value of what is labelled as 'social work theory':

“.... social workers don't feel very competent and very confident about their own theoretical knowledge, so they sort out theory rather than building theory, they sort it out, they've plucked it from different places, so I think it doesn't hang together necessarily well, ..."

(English Interviewee one)

The meaning attached to the term 'social worker' is similar in both countries where it is used to denote someone who is not just engaged in social care roles, but who is in a responsible position and recognized as a qualified practitioner, drawing on university-level knowledge. In the United Kingdom the term 'social worker' is now a protected title, requiring a certain level of professional qualification and registration as we have seen.

As we have also noted, this is not the case in Sweden although the term is generally used to denote a similar kind of qualified employee rather than, say, those engaged in routine care of the elderly. Even so, there are similar experiences of social work practice although the heart of social work in Sweden is to be found in its relation with the clients, in the interaction between the social worker and the client. This is emphasized in different Swedish government reports, for example:

"The essence of social work is the actual client work, and particularly what happens in the encounter between social worker and client. A trusting collaboration between the individual and social services staff and respect for the individual's personal integrity is therefore of great importance for the quality. It is essential that the social services show sensitivity and empathy in the individual's circumstances and that he has the insight and real influence over the actions available "

(SOU 2005:34, pp. 85).

Recognition of the difficulties of defining what social work is, and how it should be practiced, seems to have been around since its conception. It is instructive, for example, to refer to an early article on social work education in the United States, published in 1921 (Steiner, 1921), not least since Social Work in the US has had a significant impact on British social work in particular (e.g. Younghusband, 1981). The following interviewee illustrated this point:

"... I think social workers, although they have power, and often statutory power, actually feel very powerless, and they've tried to create this body of knowledge to make themselves feel better ... and ... to make themselves look more professional, but actually that knowledge is then disempowering even further, because nobody actually really understands it ..."

(English Interviewee one)

Having established that the term social work had 'come to be an accepted designation for a large group of specialized activities in the field of social betterment' (Steiner, $1921 \mathrm{p}$. 475), Steiner traced the early and diverse beginnings of social work education, while recognizing that any such project is beset by difficulties, including the diverse nature of occupational practice. These difficulties include, as he analyses them, divisions based on what might, from a later perspective, be seen as 'client' groups (the elderly, those with learning difficulties and mental health problems, children and families and so on), but also differences based on whether social workers are engaged in remedial work or tackling the root causes of social problems. He also recognized the different methodological and theoretical bases of interventions. While advocating a particular form of social work education which brings together sophisticated social science thinking with practice he recognized that 'what should constitute the fundamental courses that should precede the highly specialized vocational studies is doubtless a matter about which general agreement cannot now be reached.' (Steiner, 1921 p. 318). The above quote illustrates this quite nicely.

The second interviewee from England acknowledged these difficulties but presented a different perspective on the potential value of theoretical 'models' for social work practice:

“... many people have theorized and worked on [this] for decades and without ever agreeing among themselves. And that is practice theory; what is it and where does it come from, who invented it so to speak, yeah? Was it, did it just grow sort of descriptively out of practice, did people abstract it from their practice and describe it in general terms, yeah, or were certain academics or theoreticians suggesting something which then the practitioners took on as 'well this is a very nice way to describe our work, it makes us sound more professional",

(English Interviewee two).

"You need skills to do it, but you also to have an understanding of what the model is, otherwise you don't know what it is that you're trying to do"

(English interviewee two)

These examples illustrate the inter-connectedness of social workers' ideas about knowledge, power, values and identifications with ways of working. The combination of these elements is however expressed differently in each of these English cases, even whilst the underpinning values based on the importance of relationships with 'clients' are very similar for each social worker.

In the study in Sweden, interviews were conducted with social work managers who dealt with individuals and families, regarding various methods of social work, and in these interviews the focus was on evidence based practice, introduced into social work as a uniform scientific method to be introduced in all municipalities. Evidence-based practice 
was considered to be rooted in the social worker's professional knowledge of social work, the users' needs and preferences, as well as scientific knowledge concerning treatment:

"Well it is after all, there has become more and more that use, and become trained in ... so there become daily tools; it's there and it's great that it becomes uniform ..."

(Swedish Interviewee one)

"No, not like this, [that] I do not, but what I see of child investigations, or judgment that then it might make it solid and square [limited], at the same time, but I do not know, I do not, [there are] drawbacks as much as benefits",

(Swedish Interviewee one)

[Interviewer: What do you mean square, are you thinking that you might forget to ask something or?]

"Mmm find out anything, etc. or something else, but it is tied in some way and then you get it, then is it good enough or do I know more. But just that it will be as one, unified structure how to work, I see the biggest gain with it"'

(Swedish Interviewee one)

“... it is absolutely necessary. Yes it is certainly plausible, it is evidence-based, it is scientifically proven that it is something that works. I think everyone will be looking for in the end, that which gives results at minimum cost and when we cannot afford to have home-made methods, that no one can prove""

(Swedish Interviewee two)

"We cannot gamble good money on the methods that are not effective and also might even be counterproductive. That's what we are actually grappling with today, the performance of work among health-care personnel who are really addicted. It is my opinion that we have too much staff-led activity that involves increasing dependency, and then you work in a paternalistic way, especially not gives results in personal growth and development, learning dependence. And it has a focus on nursing, health care; there is too much focus on the sick. Focus is on what is missing with the client (users), what shortcomings instead of working with what is possible, to develop healthy, what's etc"

(Swedish Interviewee two)

These professional social workers are unsure what evidence based practice is all about or what it might do for the social work profession. In another interview similar opinions were expressed. Although this social worker is positive about evidence based practice he also identifies problems with implementing evidence based practice into social work and also that it is not at any rate established. It is still something which is coming from above, a government agency (called Socialstyrelsen), but has not yet been established in the daily organizational routines of social workers:

"There is a processing time between a method tested somewhere or to be created, and that it is processed through to being categorized as an evidence-based, and also that it is made of operations at a national level, sanctioned as an evidence-based approach. In addition, there are long lead times, I would guess that we have a five, six, seven years before it is out there, out in the country, or more, I think, ten years, twelve ... I read somewhere that it gets really long time and it means that when it is evidence-based and known, and it is so cherished and so, so society has changed in different ways so it is not applicable anymore, maybe, in the worst case. Society has had time to change. And then, yes, and it goes without saying, therefore, it comes to keep up. There, I wonder how we will do in Sweden, how can we keep up when we create national guidelines and we have therefore sanctioned national evidence-based methods. We are too slow simply. Reality runs away from us"

(Swedish Interviewee two)

This is not to suggest that evidence based practice is of little or no use to social workers or clients. It is rather to point to the tensions that can arise in implementation.

As one of our English social workers remarked when discussing the use of 'knowledge' in practice:

"I don't think there's anything wrong with the knowledge as such, but it never meets up with ...either you are ..... when you're practising, you're practising more ... of course, you're drawing on knowledge all the time and you're drawing on learning, but that's not necessarily knowledge that you learnt on a course somewhere, it's knowledge that you've learnt in situ, it's your general ... your human knowledge of how to work and deal with other people"

(English Interviewee one)

Some ninety years on from the publication of Steiner's article and social work still seems to face the same issues that Steiner identified. Perhaps this is no surprise; since social work is closely linked to social policy and through a focus on 'social justice' seeks to compensate for differences between groups of people caused by social problems, being understood as the work carried out by professional social workers (Blom, Moren and Nygren, 2006). This is not to say that what might be seen as 'progress' in the process of professionalizing social work has not taken place in the period since Steiner wrote this article. Social work education and training has become established in universities in Sweden and England, whereas in 1921 such work was in its infancy. Nonetheless, in the course of its development sympathetic commentators have continually drawn attention to the issues and uncertainties it faces. Social work continually seems to be, in the words of the title of one article, 'at the crossroads' (Lymbery, 2001) - although the nature of 
the alternative routes on offer might change over time. Dominelli's (2004) recent description of social work is of 'a troubled and troubling profession', which she perceives as suffering a 'crisis of confidence' (p. 1 and 3). Interestingly Fook (2007) seeks to base social work on one of the few certainties available - that of uncertainty as the 'defining characteristic of social work'. That is, she suggests, social workers have to work with uncertainty in social relationships and social contexts.

If social work is continually at a crossroads, however, we might expect to see commentators expressing preferences for particular routes and from Steiner (1921), through Younghusband (1964) and on to later writers such as Stevenson (2005), Fook (2007), and Ferguson and Woodward (2009) there has been no shortage of guides pointing in one direction or another and encouraging social workers to follow their lead. Whittington and Holland (1985) also produced an influential overall framework for social work theory, showing several possible directions, which has continued to be used by other social work theorists such as Malcolm Payne (2005). In Sweden the British writer Payne's text Modern Social Work Theory (2002) has probably been and remains, according to Lundström and Hessle (2002), one of the most influential in establishing a theoretical base that has been influential in social work education. This is part of the explanation for social workers having similar conceptions of their occupation in both countries, where social work is seen as professional work providing support to people with a variety of social needs and problems - whether these are vulnerable children or families, or adults facing difficulties associated with ageing, disability or mental health.

Furthermore, there can be tensions between the application of evidence based practice and consumerism as, despite attempts to involve consumers in the collection and assessment of evidence, there are inevitably difficulties over what and how evidence is presented to lay consumers as well as in their capacity to evaluate it (see Trinder, $2000 \mathrm{pp}$. 233-235). Given these difficulties there is at least the potential for evidence based practice to be used by practitioners as a means of bolstering their control in the relationship, even if they must do so under conditions of responsible autonomy (Dent 1993) in which the managerial scrutiny of practitioners could become unrelenting. It is important to recognize, also, that any move towards evidence based practice is likely to be part of a process of depoliticising policies and practices since what matters is what works, and not necessarily the values upon which policies and practices rest or those they promote.

\section{Conclusions}

In this article we have considered some of the contemporary challenges of social work in Sweden and England, emphasizing similarities as well as differences. We have also considered recent changes that have seen the development of neo-liberalism in the two countries concerned, as well as the new public management that acts as its organizational glue, to introduce the disciplines of the market through private sector managerialist technicism and performativity to reinforce and embed principles of competition, individualism, self-responsibilization and accountability; and to neutralise or depoliticise debate. The implications for social work and social workers, we contend, have been to exacerbate the uncertainties and tensions with which they have lived since their profession's inception.

Some clear differences have appeared through for example the impact of neo-liberalism, its influence being felt later in Sweden, along with a less developed third sector. England has also developed 'personalised' care for older people through the provision of funding that could be used for private care in place of direct State service provision. However, in both countries the professional identity of social workers in a local authority context is dependent on a social worker's specialism. There are for example differences between those social workers who specialize in care for older people and people with disabilities and those who specialize in working with children and individual families.

Yet the change which appears with evidence based practice has had an impact in both countries, and is discussed in a similar way by the respective professional social workers. In what way it will come to affect their work is still unclear and there are still more questions rather than answers as to what the effect will be in the long run. However, what has changed is the relation between managers and professional social workers where evidence based practice can be described as more of a tool that should govern performance instead, it could be argued. Of being used to support social workers.

The changes identified here are, of course, closely connected to political ones, evident in the trenchant neo-liberalism of the UK, and its circumscribed variation in Sweden. The shifting nature of social worker's positions, and the absence of any ontological certainty, stems from several sources that seem unlikely to diminish (Dominelli 2004). Social work has always faced the changing and fickle winds of political movement as well as of intellectual fashion but now contends with the shifting currents of social and organizational change, buffeted by the cold winds of neo-liberalism and performative managerial fiat. It appears that the uncertainties that have bedevilled social work from its inception are likely only to be exacerbated by the neo-liberal winds of change and the performativities of managerialism that have sought to reshape values and norms through scientifically instrumental rationality. The only prediction we would be inclined to make is that the future of social work will probably be like the past: where social workers need to be ready to embrace an occupational identity forever in movement; uneasy about what it is, uncertain about what it is becoming.

However, if we employ a relational concept of identity (Hunter, 2003) we might see the occupation's very survival as a distinct identity as a product of the transactions of its 
members with other occupations, clients and political actors (see also XX and Author, 2001). Faced with external threats and the need to define itself, there is an understandable desire to try to clarify what it is, what it does, how it does it, and how this makes it different from other types of work. How this is done is an area where the two countries do seem to differ : in England, the creation of a 'protected title' for social workers and the work of the Task Force on Social Work (Social Work Task Force, 2009) served to defend an existing occupational identity, this task falling to trade unions and local authorities in Sweden. In considering such identity troubles, however, there is a tendency to focus on the occupation itself and for those associated with the profession to take the lead. In doing so, however, the political context should not be lost sight of as it provides constraints as well as opportunities for all the actors involved.

\section{REFERENCES}

Bergmark, Å. and Lundström, T. (2006), Metoder i socialt arbete vad är det?, in Meeuwisse, A., Sunesson, S. and Swärd, H. (Eds) Socialt Arbete. [Social Work] En grundbok, Natur och Kultur, Stockholm, Sweden, pp. 166-182.

Blom, B., Morén, S. and Nygren, L. (Eds), (2006), Kunskap i socialt arbete. Om villkor, processer och användning, Natur \& Kultur, Stockholm, Sweden.

Carey, M. (2008), Care management unleashed: enduring ethical tensions 20 years after the Griffiths Report, 1988, Ethics and Social Welfare, 2, (3), November : :308-316.

Clarke, J. (2004), Changing Welfare, Changing State: New directions in social policy, London, UK: Sage.

Clarke, J. and Newman, J. (1997), The Managerial State, London, UK: Sage.

Dent. M. (1993), Professionalism, Educated Labour and the State: Hospital Medicine and the New Managerialism, The Sociological Review, 41 ( 2) : $244-273$.

Dent, M. and Whitehead, S. (2002), Introduction: Configuring the 'new' professional., in

Dent, M. and Whitehead, S. (Eds) Managing Professional Identities: Knowledge, performativity and the 'new' professional,London, UK : Routledge. .pp. 1-16.

Dent, M. (2003), Remodelling Hospitals and Health Professions in Europe. Basingstoke, UK: Palgrave,.

Dominelli, L. (2004), Social Work: Theory and Practice for a Changing Profession,. Oxford, UK. Blackwell/Polity Press,

Eliasson, B. (2010) Konsten med samverkan: från idéer till praktik. Licentiate thesis / Luleå University of Technology

Erikkson, L (2014) The understandings of social pedagogy from Northern European perspectives Journal of Social Work, 14 (2): 165 - 182 DOI: $10.1177 / 1468017313477325$

Esping-Anderson, G (1990) The Three Worlds of Welfare Capitalism, Cambridge., UK: Polity Press,
Exworthy, M. and Halford, S. (1999), Professionals and the New Managerialism in the Public Sector, Buckingham, UK: Open University Press,

Ferguson I. and Woodward, R. (2009), Radical Social Work in Practice: Making a difference, Bristol, UK: Policy Press.

Fook, J. (2007), Uncertainty; the defining characteristic of social work?, in Lymbery, M. and. Postle, K. (Eds), Social Work, A Companion to Learning, Sage: London, pp. 30-39.

General Social Care Council (2011), Protection of title [online] available at:

http://www.gscc.org.uk/page/29/Protection+of+title.html

E Harlow, E Berg, J Barry, J Chandler (2013) Neoliberalism, Manageralism and the Reconfiguring of Social Work in Sweden and the United Kingdom Organization, 20 (4), 534-550.

Harvey, D. (2005), A Brief History of Neoliberalism, Oxford, UK: Oxford University Press,.

Hollander, A. (2006), Juridik och socialt arbete, in Meeuwisse, A., Sunesson, S. and

Swärd, H. (Eds) Socialt Arbete. [Social Work] En grundbok, Natur och Kultur, Stockholm, Sweden, pp. 110-128.

Holmberg, I. and Henning, R. (2003), Offentlig Ledarskap - Om förändring förnyelse och nya ledarideal [Public Leadership], Studentlitteratur, Lund, Sweden.

Hood, C., Scott, C., James, O., Jones, G. and Travers, T. (1999), Regulation Inside Government: Waste-Watchers, Quality-Police and Sleaze-Busters, Oxford, UK: Oxford University Press, Oxford.

Hugman, R. (2005), Looking back: The View From Here, British Journal of Social Work, 35, (5) : 609-620.

Hunter S (2003) A Critical Analysis Of Approaches To The Concept Of Social Identity In Social Policy Critical Social Policy, $23(3): 322-344$.

Kasza, G. J. (2002), The Illusion of Welfare Regimes, Journal of Social Policy, 31 (2):271-287.

Lawler, J. (2000) The Rise of Managerialism in Social Work in Harlow, E. and Lawler, J. (eds) Management, Social Work and Change Aldershot, UK: Ashgate.

Leach S., Stewart, J. and Walsh, K. (Eds), (1994), The Changing Organisation and Management of Local Government., Basingstoke, UK: Macmillan .

Löfstrand, I. (2009), Professionellt föräldraskap [Professional Parenthood] Samhälleliga förutsättningar för familjehem för tonåringar, Luleå, Sweden: Luleå Tekniska Universitet licentiate Thesis,

Lundström, T. and Hessle, S. (2002) Preface to the Swedish publication, in Payne, M. (2002), Modern teoribildning $i$ socialt arbete, Natur och Kultur, Stockholm (Swedish edition).

Lymbery, M. (2001), Social Work at the Crossroads, British Journal of Social Work, 31 (3): 369-384.

Nygren, L. Blom. B. and Moren, S. (2006), Kunskap i Socialt Arbete [Knowledge in Social Work]", in: Nygren, L. Blom. B. and Moren, S. (Eds) Kunskap i Socialt Arbete Om villkor, processer och användning [Knowledge in Social Work] Natur och Kultur, Stockholm.

Olofsson, J. (2009), Socialpolitik, Varför, hur och till vilken 
nytta?, , Stockholm, Sweden: SNS, Förlag.

Oscarsson, L. (2009), Evidensbaserad Praktik inom socialtjänsten - En introduktion för praktiker, chefer, politiker och studenter, Sveriges kommun och Landsting och SKL Kommentus, Stockholm.

Payne M. (2002) Modern Social Work Theory Basingstoke, UK: Macmillan; Swedish, 2002

Payne, M. (2005), Modern Social Work Theory. Basingstoke, UK: Palgrave, (3rtd edition).

Pollitt, C. and Bouckaert, G. (2000), Public Management Reform: A comparative analysis, Oxford: Oxford University Press,.

Rosen A. (2003), Evidence-based Social Work Practice: Challenges and promise, Social Work Research, 27 (4):197-208.

Social Work Task Force (UK) (2009) Building a Safe, Confident Future: The Final Report of the Social Work Task Force: November 2009. [Online] Available at $\mathrm{http}$ ://publications.education.gov.uk/default.aspx?PageFunction $=\mathrm{p}$ roductdetails\&PageMode $=$ publications $\&$ ProductId $=$ DCSF-011142009 (Accessed: July 30 2010).

SOU (2005:34) Socialtjänsten och den fria rörligheten

Steiner, J.F. (1921) Education for Social Work, American Journal of Sociology, 26, (4):. 475-518.

Stevenson, O. (2005), Genericism and Specialization: the story since 1970, British Journal of Social Work, 35, (5): 569-586.

Trinder, L. (2000), A critical appraisal of evidence based practice, in Trinder, L. with Reynolds, S. (Eds) Evidence-Based Practice: a critical appraisal, Oxford, UK: Blackwell,: 212-241.

Wahlberg, S. (2006) Samhällsarbete-strategier för ett radikal och humanistiskt socialt arbete. Stockholm, Sweden:. Norstedts Juridik $\mathrm{AB}$,

Walton, R. (2005), Social work as a Social Institution, British Journal of Social Work, 35, (5): 587-607.

Whittington, C and Bell, L (2001) Learning for interprofessional and inter-agency practice in the new social work curriculum: evidence from an earlier research study Journal of Interprofessional Care, 5, (2): 153 - 169

Whittington, C. and Holland, R. (1985), A Framework for Theory in Social Work, Issues in Social Work Education, 5: 25-50.

Younghusband, E. (1981), The Newest Profession: A short history of social work, Sutton. UK, IPC Business Press,

Younghusband, E. (1964), The Social Services and Social Work, London., UK: George Allen and Unwin, 